\title{
A Systematic Literature Review on Strategic Information Systems Planning: Insights from the Past Decade
}

\author{
Alireza Amrollahi \\ School of Information and Communication Technology \\ Griffith University, Australia \\ alireza.amrollahi@griffthuni.edu.au \\ Amir Hossein Ghapanchi \\ School of Information and Communication Technology \\ Griffith University, Australia \\ a.ghapanchi@griffith.edu.au \\ Amir Talaei-Khoei \\ Agile Information System Lab, School of Systems, Management and Leadership, University \\ Technology Sydney, Australia \\ Faculty of Arts and Business, University of the Sunshine Coast Australia \\ amirtk@usc.edu.au
}

\begin{abstract}
Strategic information system planning (SISP) has been an important concern for top business and information systems (IS) managers. This paper employs a systematic literature review approach for 12 top ranking IS journals in the past 10 years in order to classify them based on their focus levels, research topics, and research methods. Our search resulted in 45 papers which are categorized into four focus groups, three context groups and six topic groups. The results indicate that most of the research focus to date has been on the alignment and development of plans. Researchers have paid more attention to the context as the focus of research, the firm as research context and the quantitative approach as research method. The results may be beneficial to show new researchers the current status and research gaps and for practitioners who want to ascertain valuable topics in the literature that help them with their business problems.
\end{abstract}

Keywords: Strategic Information System Planning, Information System Planning, SISP, Information System Alignment. 


\section{Introduction}

Since 1980, strategic planning has been one of the top ten management concerns as reported by Society for Information Management (Luftman and Ben-Zvi, 2011).Huge investment in information systems (IS)/information technology (IT) could be a reason for this concern. A survey of 260 Fortune 1000 manufacturing firms shows that the median company expends $\$ 9.6$ million per annum on IT services, which is estimated to be $15 \%$ of the total cost for research and development (R\&D) and about $0.3 \%$ of total sales (Kleis et al., 2012). It was also estimated that the investment in IS would be over $\$ 450$ billion by 2010 (Chen et al., 2010).

Early research questioned the value and effectiveness of these investments in previous decades. Then, in 1982, strategic information system planning (SISP) was introduced as a common approach to ensure that, aligned with organizational business strategy, investment in IS/IT resulted in delivering value, effectiveness and competitive advantage to the organization. The proliferation of Internet based computing, outsourcing, personal computers and user applications are other factors that have caused the evolution of SISP in recent years (Grover and Segars, 2005).

The importance of the topic has also attracted many researchers to focus their studies on different aspects of SISP, like aligning it with business strategy, its effectiveness, techniques for development, and so on. But the vast domain of research and variety in focus, context and methods of research have made the topic confusing for both researchers and practitioners who want to start new research or benefit from the current body for their work.

The body of research in the field of SISP has grown greatly in recent years. According to the Google Scholar database, the total amount of papers which contained the phrase "Strategic Information System Planning" in 2011 was more than twice the number of papers in 2000. Similar statistics could be found with other related keywords, such as "Information Strategic Planning", "Information System Planning", "Strategic Information Planning", and so on. To date, this literature has led to many influential results and researchers in the field have attempted to provide answer for questions like: Who are contributors to SISP? Who should support SISP? How can SISP benefit organizational goals? What factors impact the effectiveness of SISP? How can the effectiveness of SISP be measured? What are the best practices in SISP? And so on.

This significant attention in the field from academia has motivated us to make an effort to survey recent literature and to try to draw a picture of the areas of study as well as topics, such as research focus, context and method. To do so, we searched 12 top ranking journals in the field of IS with related phrases and, by this review, made an attempt to answer the following research questions:

RQ1. What has the literature of SISP focused on?

RQ2. In which contexts has SISP research been conducted to date?

RQ3. Which areas have been addressed by researchers who work in the field of SISP?

RQ4. Which methods and techniques have been employed in SISP research?

The result could be beneficial for future researchers in terms of a better understanding of the field, classifying their research and ascertaining any research gaps. It would also benefit practitioners by providing a short introduction and directing them to the correct area that may solve their business problems.

The remainder of this paper is organized as follows: Section 2 gives an overview of SISP and describes its advantages and disadvantages. Section 3 describes the method which we used to form our pool of research. Section 4 illustrates the results of the systematic literature review and the proposed classification. We finally discuss the 
results of the study in Section 5 and provide some recommendations for future research.

\section{Literature Review}

Strategic use of IS was first raised in research papers in the early 1980s (Charles Wiseman, 1984; Rackoff et al., 1985; Synnott and Gruber, 1981). Early research in the field focused on "gaining competitive advantage", but after the appearance of research doubting the effectiveness of IS/IT in organizations (known as the "productivity paradox") it addressed issues like effectiveness and alignment of IS with organizational goals and strategies (Pant and Hsu, 1995). These issues were so influential on the IS/IT literature of the 1980s and 1990s that the decades were named as "Strategic Information System Era" (Pant and Hsu, 1999).

Chen et al. (2010) define three conceptions of IS strategy in the literature:

-IS strategy as the use of IS to support business strategy

-IS strategy as the master plan of the IS function

-IS strategy as the shared view of the IS role within the organization

The concept of SISP in this framework could be matched with the second topic which defines IS strategy as a plan that defines the requirements for IS and allocates these resources in an efficient way.

However, based on different functions in an organization, there are different explanations for SISP in the literature. Lederer and Sethi (1988), for example, define it as "the process of identifying a portfolio of computer-based applications that will assist an organization in executing its business plans and consequently realizing its business goals" which is focused on implementation. While Sabherwal and Chan (2001) in their definition which is adopted from Bechor et al. (2010) focus on the planning phase: "the process of strategic thinking that identifies the most desirable IS on which the firm can implement and enforce its long-term IT activities and policies". (p.3)

On the other hand, Doherty et al. (1999) definition is focused on the role of SISP in delivering competitive advantage to the firm: "an exercise or on-going activity that enables organizations to develop priorities for information system (IS) development. Applications are chosen for their alignment with business objectives or their capacity to create significant impact on the organization's competitive positioning". (p.1)

During a review of the related literature, Earl (1993) recommends these four areas which SISP targets:

-Aligning investment in IS with business goals

-Exploiting IT for competitive advantage

-Directing efficient and effective management of IS resources

-Developing technology policies and architecture

In any event, different terms have been suggested for the above topics: information systems strategy for the first two areas, information management strategy for the third, and information technology strategy for the last (Earl, 1989).

Generally, five categories of SISP approach have been introduced by Earl (2003): business-led, method-driven, administrative, technological and organizational. These approaches are different according to their emphasis, basis, ends, methods, nature and influence. For example, while the businessled approach ends in a "plan" for the firm, the technological approach will deliver "architecture" and the administrative approach will bring a "portfolio" of projects to the firm.

Since the introduction of SISP, many different approaches and techniques have also been introduced for the development of these plans. Pant and Hsu (1995) categorized these techniques into two groups: 
A Systematic Literature Review on Strategic Information Systems Planning / Amrollahi et al.

-Impact methodologies: these methodologies help the organization to create and justify new uses of IT and most of them are based on the strategic management literature including "Value Chain Analysis" (Porter, 1998), "Critical Success Factor Analysis" (Rockart, 1979)

-Alignment methodologies: the aim of theses methodologies is aligning IS objectives with organizational goals. This group includes: "Business Systems Planning (BSP)" (Zachman, 1982), "Strategic Systems Planning (SSP)" (Corporation, 1986), "Information Engineering"(Martin, 1982), "Method/1" (Andersen, 1988).

In addition to the techniques and cases of SISP development, many different streams of research have also been followed in the field. Topics like effectiveness and evaluation of SISP (Grover and Segars, 2005; Wang and Tai, 2003), influence of leadership and personnel (Byrd et al., 2006; Mirchandani and Lederer, 2012), effect of SISP on organizational performance (BulchandGidumal and Melián-González, 2011), and so on have been addressed in the related literature. However, we have not found any classification in the related literature which provides an insight into possible research topics and current methods, and the contexts which have been studied to date.

\section{Research Methodology and Framework}

\section{Research Framework}

In the current paper, we aim to draw a picture of the current research in the field of SISP and its related approaches. To do so, we selected the systematic literature review approach which is introduced in detail in next section.

Our research is at the level of reviewing 12 top ranked information systems journals: European Journal of Information Systems, Information and Management, Information Systems Journal, Journal of Information Technology, Journal of Management
Information Systems, MIS Quarterly, Communications of the Association for Information Systems, Information Technology and People, International Journal of Medical Informatics, Journal of Computer Information Systems, Journal of the Association of Information Systems, The Journal of Strategic Information Systems.

In these journals we searched for those papers which addressed topics like "Strategic Information System Planning", "Information System Planning", "IT Planning" and related topics (See the sources and keyword section for more details). While our final aim has been proposing general classifications for the research in the field, we have excluded irrelevant papers and then arrived to our final set which is the basis of our analysis and categorization (our approach is explained in detail in inclusion/exclusion criteria and data analysis sections).

\section{Research Method: Systematic Literature Review}

A systematic literature review is a methodical way to identify, evaluate, and interpret the available empirical studies conducted on a topic, research question, or a phenomenon of interest (Kitchenham, 2004).

In order to do this systematic literature review, we used guidelines provided by Kitchenham (2004) and Kitchenham and Charters (2007) which suggest five different steps for review: (1) identify resources; (2) study selection; (3) data extraction; (4) data synthesis; and (5) write-up study as a report. The detailed process of selecting and reviewing the papers is depicted in Figure 1.

To follow these steps we adopted the method used by Ghapanchi and Aurum (2011) and first selected twelve journals and searched with our predefined set of keywords. Our initial search resulted in 343 research papers. We then started to exclude irrelevant papers 


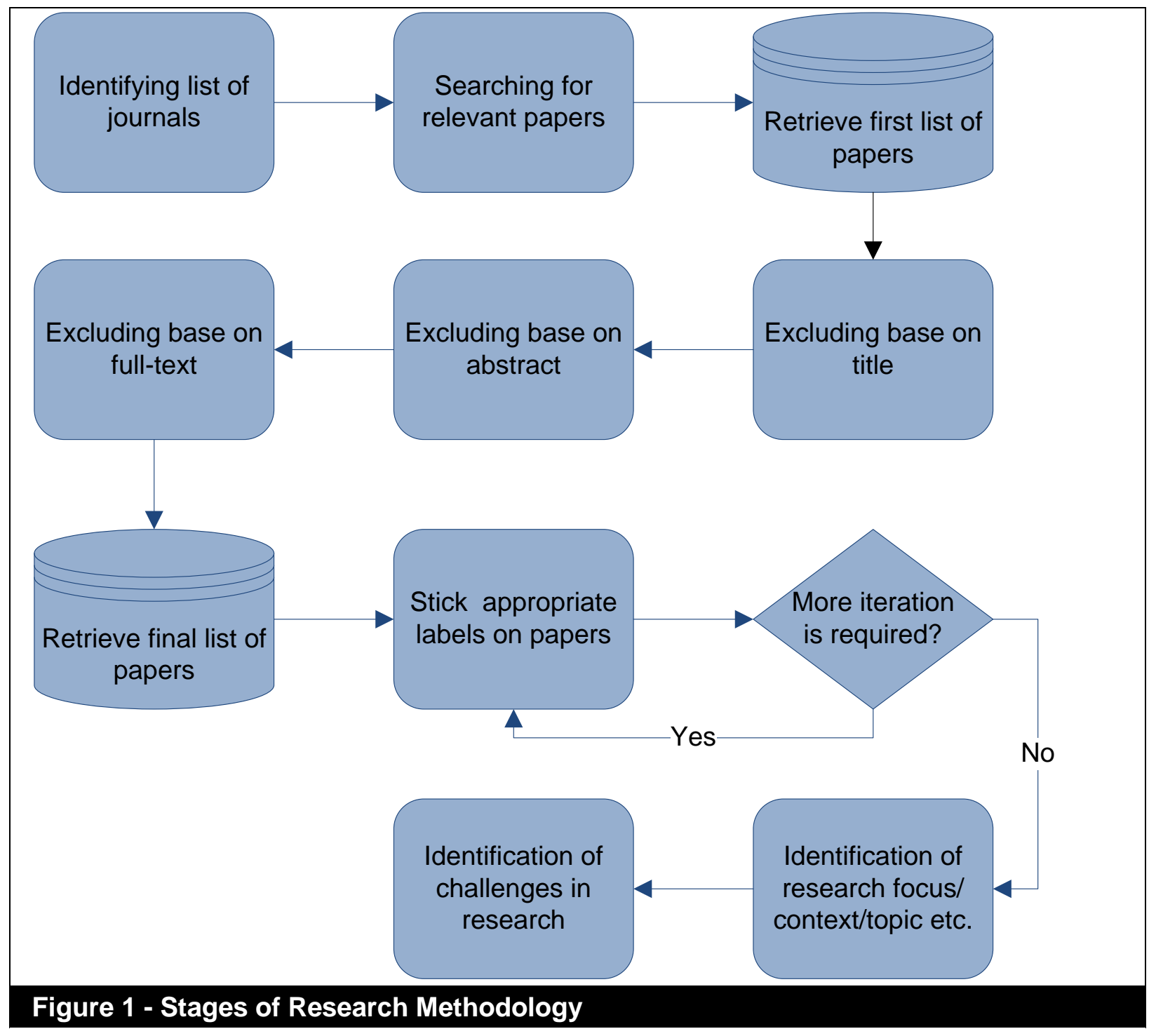

when reviewing titles, abstracts and full-text papers. After in-depth study of the papers we arrived to final list of 45 papers and performed our analysis and classification based on those papers.

\section{Sources and Keywords}

We tried to search the top ranking journals in the field of IS. To do so, we referred to "Excellence in Research for Australia (ERA)" 2010) which is one of the best references available to measure the quality of research. We selected 12journals ranked $A$ and $A^{*}$ in this list: European Journal of Information Systems, Information and Management,
Information Systems Journal, Journal of Information Technology, Journal of Management Information Systems, MIS Quarterly, Communications of the Association for Information Systems, Information Technology and People, International Journal of Medical Informatics, Journal of Computer Information Systems, Journal of the Association of Information Systems, The Journal of Strategic Information Systems. (See table 1)

We searched for the following keywords on title, keywords and abstract of papers: 


\begin{tabular}{|l|l|l|}
\hline Table 1 - List of Journals and Distribution of Research Papers & Rank & $\begin{array}{l}\text { Number of } \\
\text { papers }\end{array}$ \\
\hline Journal & $A^{*}$ & 3 \\
\hline European Journal of Information Systems & $A^{*}$ & 9 \\
\hline Information and Management & $A^{*}$ & 2 \\
\hline $\begin{array}{l}\text { Information Systems Journal: an international journal promoting the study } \\
\text { and practice of information systems }\end{array}$ & $\mathrm{A}^{*}$ & 6 \\
\hline Journal of Information Technology & $\mathrm{A}^{*}$ & 6 \\
\hline Journal of Management Information Systems & $\mathrm{A}^{*}$ & 2 \\
\hline MIS Quarterly & $\mathrm{A}$ & 3 \\
\hline Communications of the Association for Information Systems & $\mathrm{A}$ & 2 \\
\hline Information Technology and People & $\mathrm{A}$ & 2 \\
\hline International Journal of Medical Informatics & $\mathrm{A}$ & 3 \\
\hline Journal of Computer Information Systems & $\mathrm{A}$ & 1 \\
\hline Journal of the Association of Information Systems & $\mathrm{A}$ & 6 \\
\hline The Journal of Strategic Information Systems & 45 & \\
\hline Total & \\
\hline
\end{tabular}

"Strategic Information Systems Planning" or "Strategic Information Systems Plan" or "Strategic Information System Planning" or "Strategic Information System Plan" or "SISP" or "Strategic Plan" or "Strategic Planning" or "Information Management Plan" or "Strategic Information Plan" or "Information System Plan" or "Information Technology Plan" or (("Strategy" or "strategic") and "Plan" and ("Alignment" or "Fit" or "Integration" or "Linkage" or "Harmony" or "Fusion"))

\section{Inclusion / Exclusion Criteria}

In our study, we paid attention to papers which have been published in the last ten years (2002-2012). The initial search for the above phrases resulted in 343 papers. We then read the title, abstract and keywords of the papers and elaborated irrelevant papers. In this round, the research pool was decreased to 135 papers. Finally we made another round by referring to the full texts and formulated the final list of 45 papers which can be found in Appendix 1. Table 2 illustrates the process of inclusion / exclusion for our research.

\section{Data Analysis}

After identification of the relevant papers, we tried to label them with appropriate words regarding their focus, main category, context, and method. To do this, we focused on peer review of publications: one of the authors reviewed each paper thoroughly and assigned proper code to the paper for each criterion (focus, main category, context, and method). After finishing the first round of labelling, we continued to second and third rounds in order to gain a better classification. We revised some labels with better vocabulary or merged some of the categories in the second and third rounds to achieve our

\section{Table 2 - Different Stages of Inclusion I Exclusion and Number of Papers in Each} Round

\begin{tabular}{|l|l|l|}
\hline Round & $\begin{array}{l}\text { Number of Papers } \\
\text { Excluded }\end{array}$ & $\begin{array}{l}\text { Number of Papers } \\
\text { Remained }\end{array}$ \\
\hline Initial list of papers & - & 343 \\
\hline Exclusion based on title & 158 & 185 \\
\hline Exclusion based on abstract & 50 & 135 \\
\hline Exclusion based on full-text & 90 & 45 \\
\hline Final List & - & 45 \\
\hline
\end{tabular}




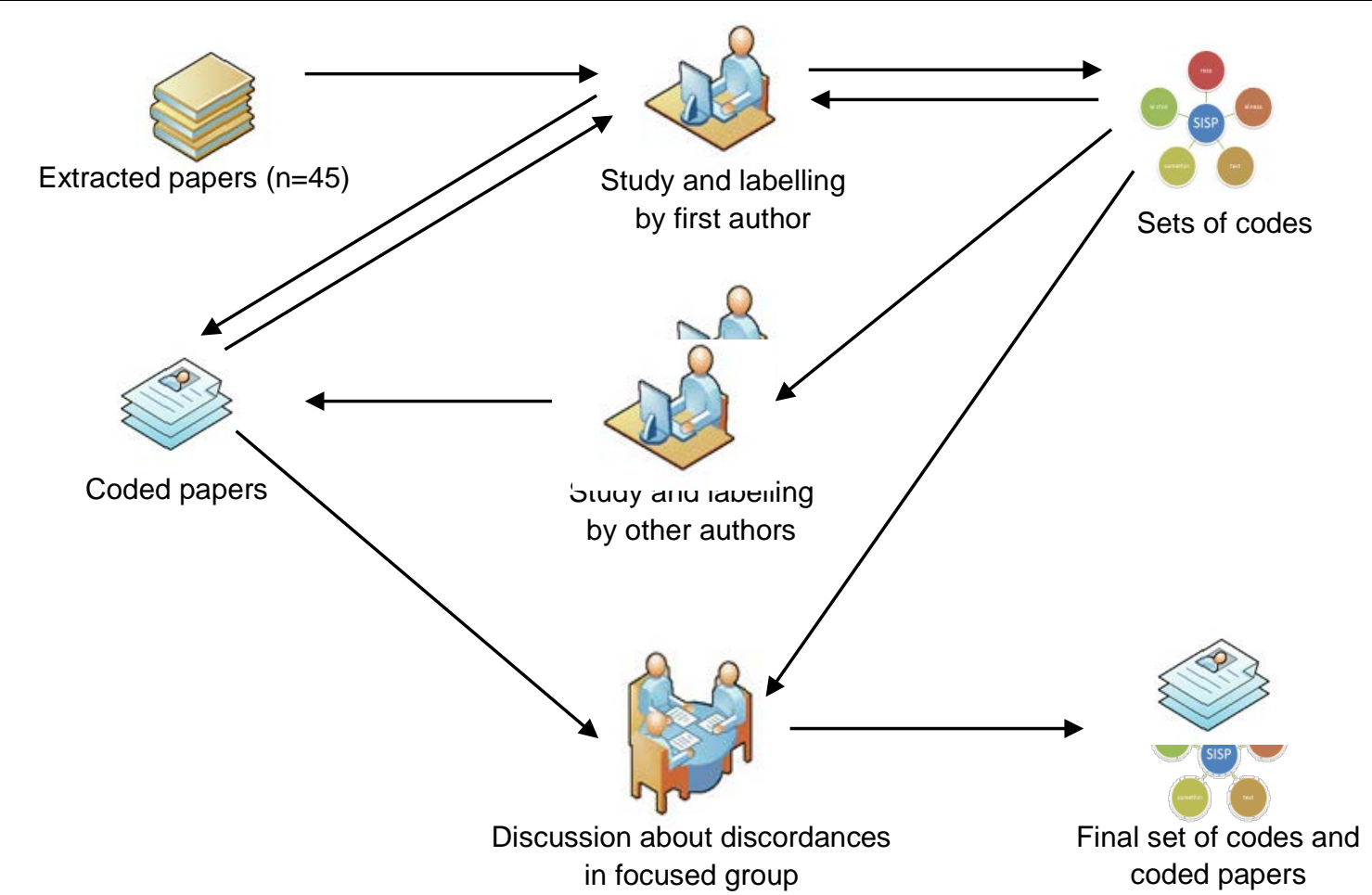

\section{Figure 2 - Data Analysis Process}

final classification, which is depicted in the results section of the paper.

Afterward, the complete set of papers and sets of final codes were presented to other two authors and they were asked to assign appropriate code to each paper or create their own code. This time proposed set of codes remained the same but five papers were assigned different codes from the first author's point of view. These five papers as well as the complete sets of codes were discussed in a meeting with six people (including three authors) and discordances were settled down during the meeting. Details can be seen in figure 2 .

\section{Results}

Our final pool of 45 papers includes a variety of topics, methods and research types. During the ten-year period of this study -as depicted in Figure 3- different falls and rises in the research can be observed. Before 2007 there was an incremental trend in number of papers and this trend stopped in 2008 but continued again in 2010. The following sections provide a description of the different classifications of the literature. 


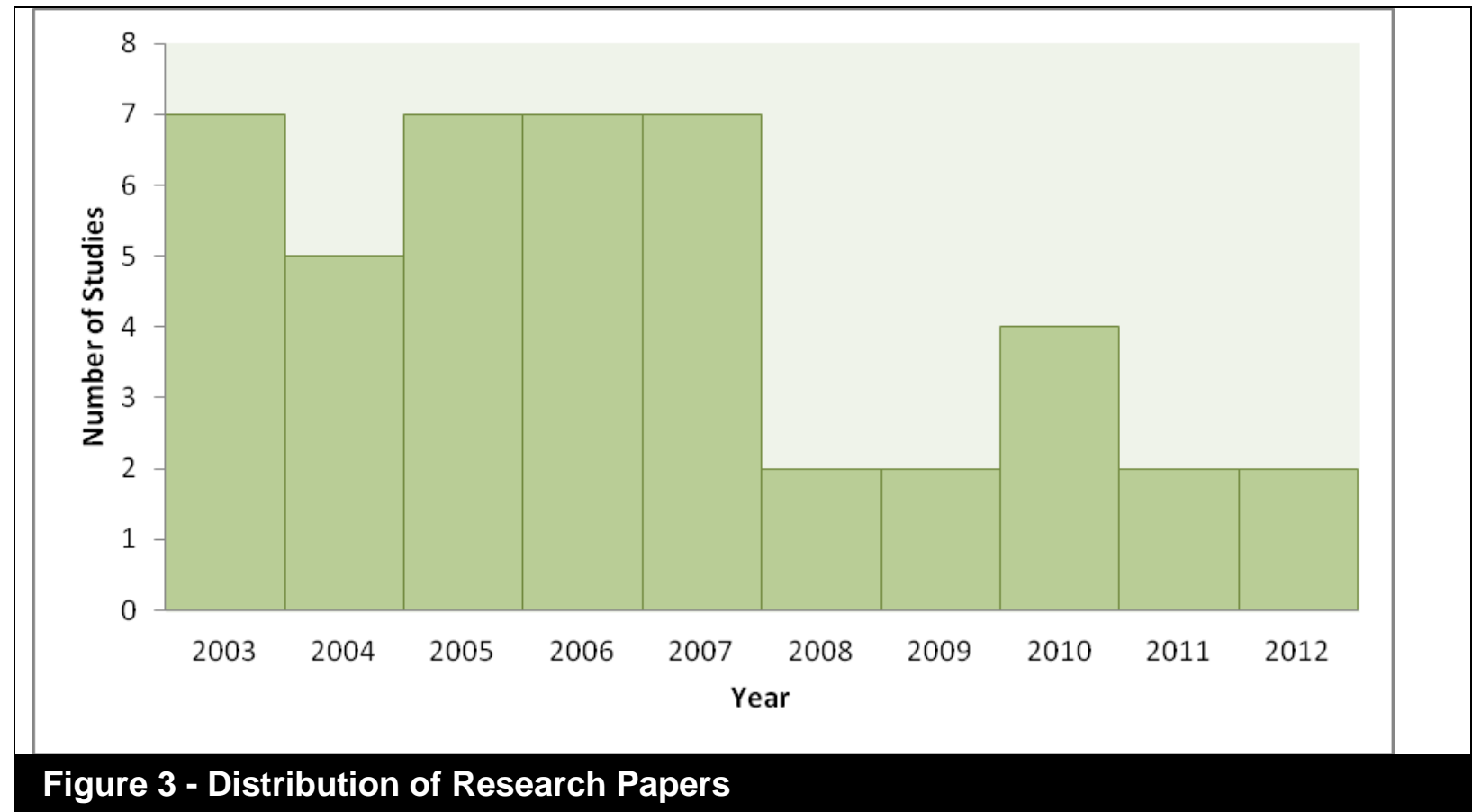

\section{Focus of Research}

After the review of the 45 selected papers, we recognized that their focus could be classified into four different categories. It is worth mentioning that, in several cases, it was impossible to allocate research to one specific category. In this case we tried to pick the area which was more highlighted in the paper. For example, (Dufner et al., 2003) studied government performance project (GPP) data in the context of the U.S. government investigating different aspects of SISP development, so we can categorize its focus as both context and tools. But, after several reviews of the research, we have found that the contribution of the research is mainly around the model itself so we categorized it as "focus on tools". Our categories include context, tools, impact and people. In the following, we briefly introduce each category.

\section{Focus on Level of Study}

Case studies and study of planning context has been subject of many papers. These papers usually address SISP in specific contexts or effect of contextual factors on planning effectiveness.
The contextual aspects of SISP, such as SISP for government, or specific industries, or specific countries are main theme of much research in this area. For example Kahraman et al. (2007) studied strategic planning for eGovernment in Turkey. In this case, strategic analysis is performed and different strategies have been prioritized with respect to the contextual factors of the Turkish government. The work of Brigl et al. (2005) and Teubner (2007) are other examples. The first reference provides a guideline for preparing strategic information management plans in hospitals and the latter one is a case study of developing SISP in a German financial services company. Both papers have addressed challenges of developing the plan in specific contexts and they both contain advices on how to deal with those challenges. Contextual factors in specific countries are another main topic of research. Chen (2010) in China, and Cohen (2008) in South Africa researched the contextual factors in the respective countries.

Other papers which studied the effect of contextual and environmental factors on the planning effectiveness were categorized in this group. Kearns and Sabherwal (2006), for example, study the possibility that the role of 
top management knowledge of IT, and the quality of planning and implementation of IT projects may boost the strategic alignment. Another example is study of environmental uncertainty by Newkirk and Lederer (2006, 2007) which show the effect of uncertainty on planning success, and how strategic awareness and strategic conception can change this uncertainty.

\section{Focus on Planning Process}

These papers mainly focus on the way in which, and the process by which, SISP could be developed and implemented in the organization. Among papers in this category, many case studies, guidelines and models can be found.

Thorogood et al. (2004) for example introduced a case study on the strategic choices and related challenges in the strategic planning of information systems. The work of Wagner (2004) is another example which introduces Enterprise Strategic Management (ESM) systems as a tool for planning in organizations.

\section{Focus on Impact}

Research in this category tends to focus on the possible impacts of SISP on other parties, such as the organization, the stakeholders, and so on. Most of the research in this category tends to evaluate the effectiveness of SISP through its impact on planning objectives, IT focus, the use of IT for competitive advantage, and so on.

Wang and Tai (2003), for example, studied the role of formalization, centralization, and organizational aspects on the fulfilment of planning objectives as the final measure of SISP effectiveness. Another study which is mainly focused on the impact and effect of planning is the work of Kearns and Lederer (2004) which mentions the use of IT for competitive advantage as the ultimate goal of SISP. This research studies the effect of the industry context, and the IT focus of the firm on the success of SISP.

\section{Focus on People}

This category of research papers tends to answer questions about how human resources and/or stakeholders in different levels of the organization could be involved in, or support, the SISP process.

Mirchandani and Lederer (2012), for example, studied how the different characteristics of jobs and autonomy may influence the planning outcome. Another example is Scott (2005) who addresses the role of different stakeholders (such as: IT planners, IT researchers, business planners, and business planning researchers) in IT planning, and the way they should collaborate to achieve the planning goals. Finally Byrd et al. (2006) addresses the influence of top management in SISP. This paper mainly investigated how the involvement of senior leadership may affect effectiveness of SISP which is measured in terms of technology integration, the application functionality and data integration.

Table 3 and figure 4, provide a definition of our proposed categories of research as well as the frequency of research in each category.

\begin{tabular}{|l|l|l|}
\hline Table 3 -Different Categories of Research Focus in SISP Literature \\
\hline Focus Category & Research Tendency & Frequency \\
\hline Level of study & How context of planning impacts SISP? & 20 \\
\hline Planning process & How SISP process could be conducted? & 17 \\
\hline Impact & What is the impact of SISP? & 5 \\
\hline People & How stakeholders can be involved or support SISP? & 3 \\
\hline Total & & 45 \\
\hline
\end{tabular}




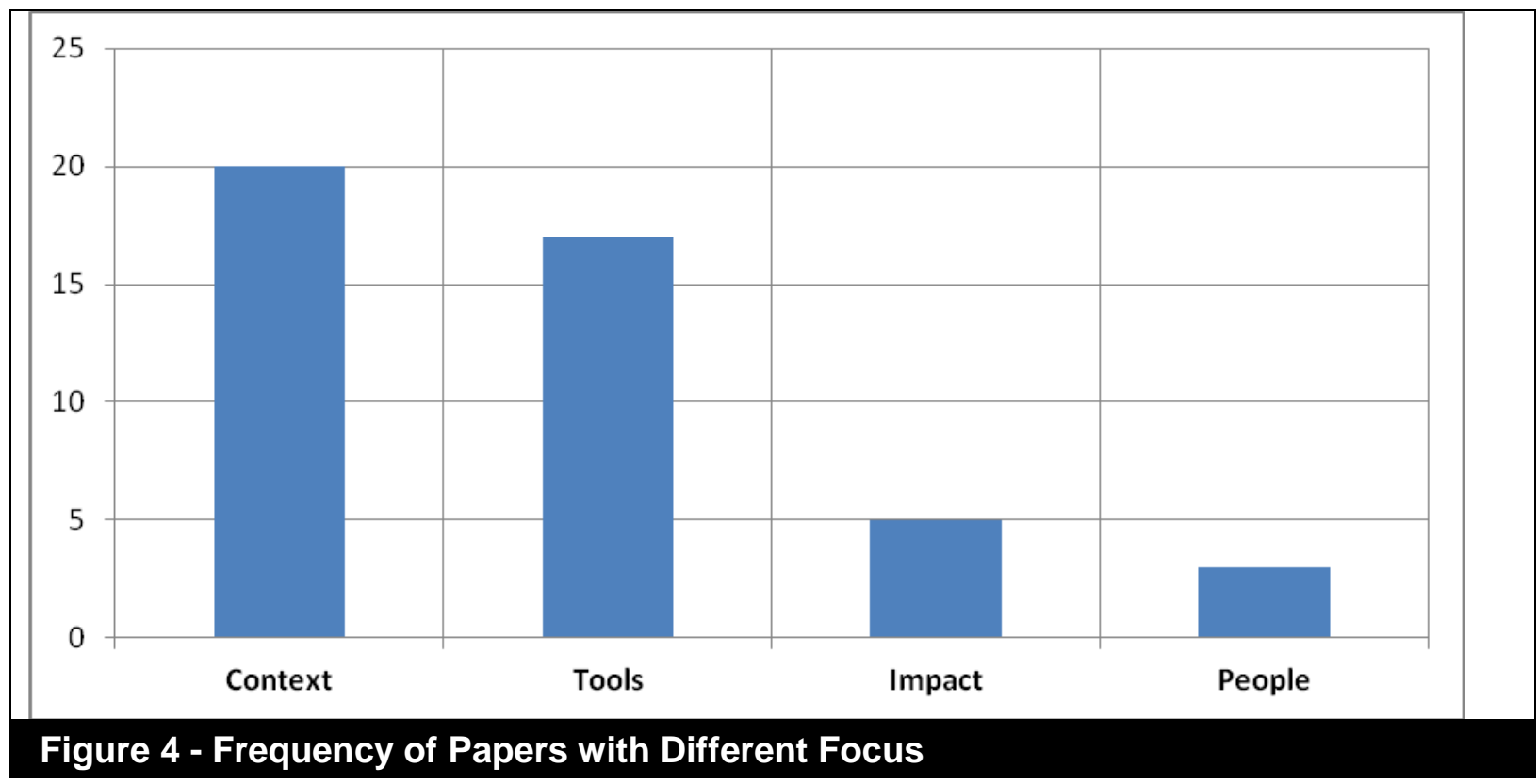

\section{Context of Research}

The context in which different aspects of SISP have been studied was another focus of our study. While reviewing the related literature, we observed that research has been conducted in three main categories: government, industry and firm. (See figure 5)

\section{Government}

Six of the research papers paid attention to different aspects of SISP in the public sector. This includes both government and sectors of government (e.g. public health). Different governments, including those in developed (Choudrie et al., 2003; Dufner et al., 2003) and developing countries (Al-Jaghoub and Westrup, 2003; Kahraman et al., 2007; Yayla and $\mathrm{Hu}, 2012$ ), were the subject of study as the research context in the literature.

\section{Industry}

We found three papers which paid attention to specific industries, including the health industry (Brigl et al., 2005), insurance (Fairbank et al., 2006) and banking (Tallon, 2010). These studies were conducted based on surveys of active experts in the field or multi-case studies in an industry.

\section{Firm}

In the literature, most of the research papers in the field, however, work around different firms (33 papers in our study). Among these papers, there are many case studies of one firm and many surveys of firms' CEOs and CIOs. These surveys have usually ignored the firm type but some of them are based on industrial lists such as the "directory of top computer executives" (Newkirk and Lederer, 2007) and "Common Wealth 1000" (Wang and Tai, 2003). On the other hand, some studies selected specific types of firms as their research context. The work of Mohdzain and Ward (2007) is an example which studies SISP in multinational organizations.

\section{Research Topics}

In this section, we present a classification of the main research areas in the field of SISP. To capture this classification, we skimmed all papers in our research pool and then made an attempt to assign a label to each one 


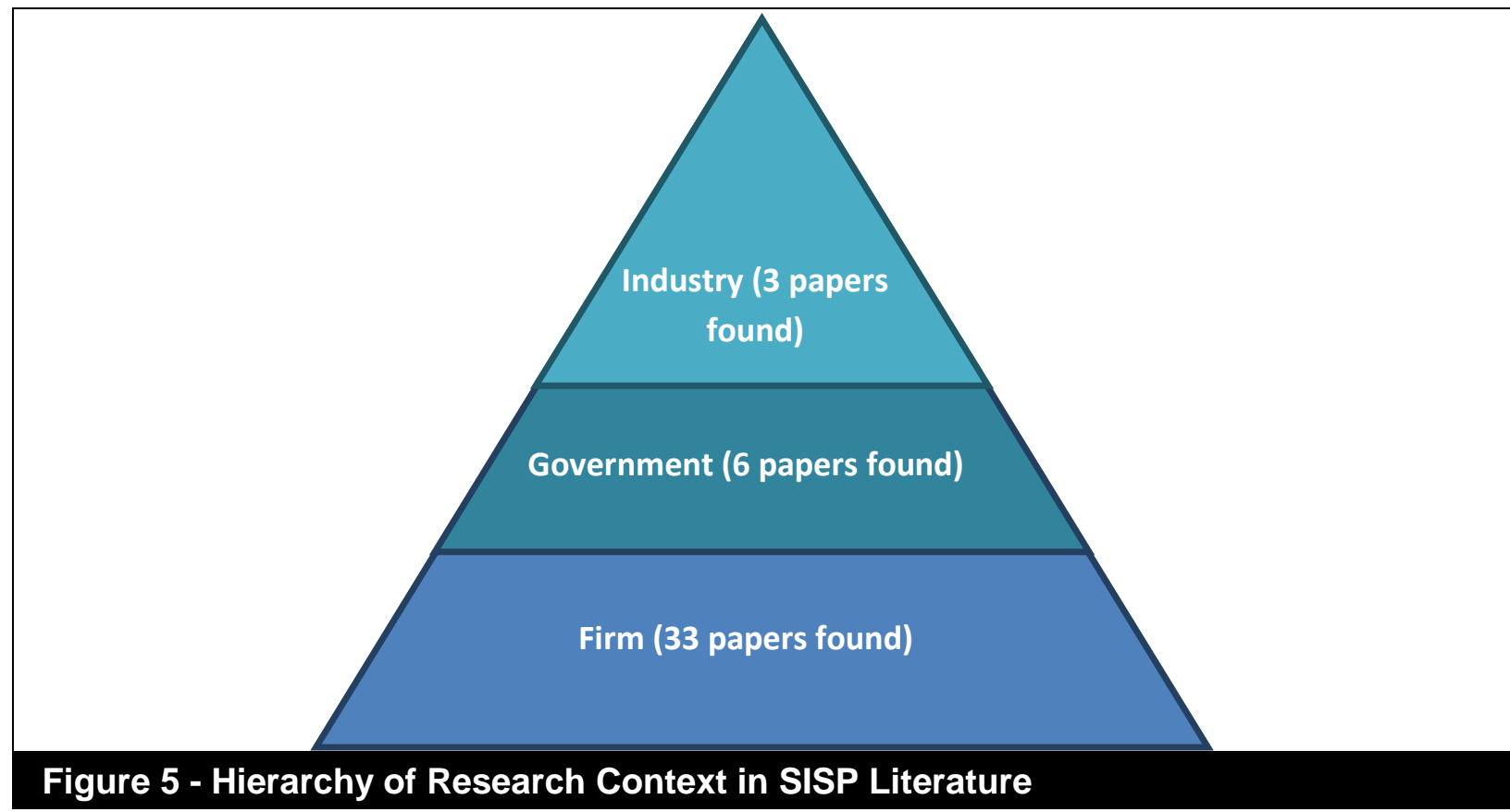

according to the main topic addressed by the paper. In the second round we revised these labels and changed some of them to more appropriate ones. After several rounds and many revisions, we finally reached six main topics in the literature. Here we introduce the six main categories addressed in the literature and provide a concise overview of each. (See figure 6)

\section{Plan Development}

Studies in this category investigate tools, techniques and best practices in developing strategic plans for IS. Ten papers which addressed different aspects of plan development were in our final pool of research.

Several case studies are found in this category which contains information about challenges and best practice in development of plans for different firms. For example AlJaghoub and Westrup (2003) introduced the strategy of the Jordanian government in the ICT section and analyse the strategy by comparing it with the cases of Singapore and Ireland. Work of Dufner et al. (2003) have another research which used the gathered data of U.S government in different states to show the current status of SISP in the country.

New models and techniques for SISP are also the subject of this category. Examples are the use of "Critical Success Factors (CSF)" by Peffers et al. (2003) which results in a new methodology called "Critical Success Chain (CSC)".Authors believe that this may help to involve more people and absorb a wider range of ideas in planning. The work of Gao (2005) is another example that uses "actor-network theory" to analyse and develop the strategy in the telecommunication sector of China. The final found example is application of "strength, weakness, opportunity, threat (SWOT)" and "analytical hierarchy process (AHP)" by Kahraman et al. (2007) in prioritization and sensitivity analysis of e-Government strategies. 


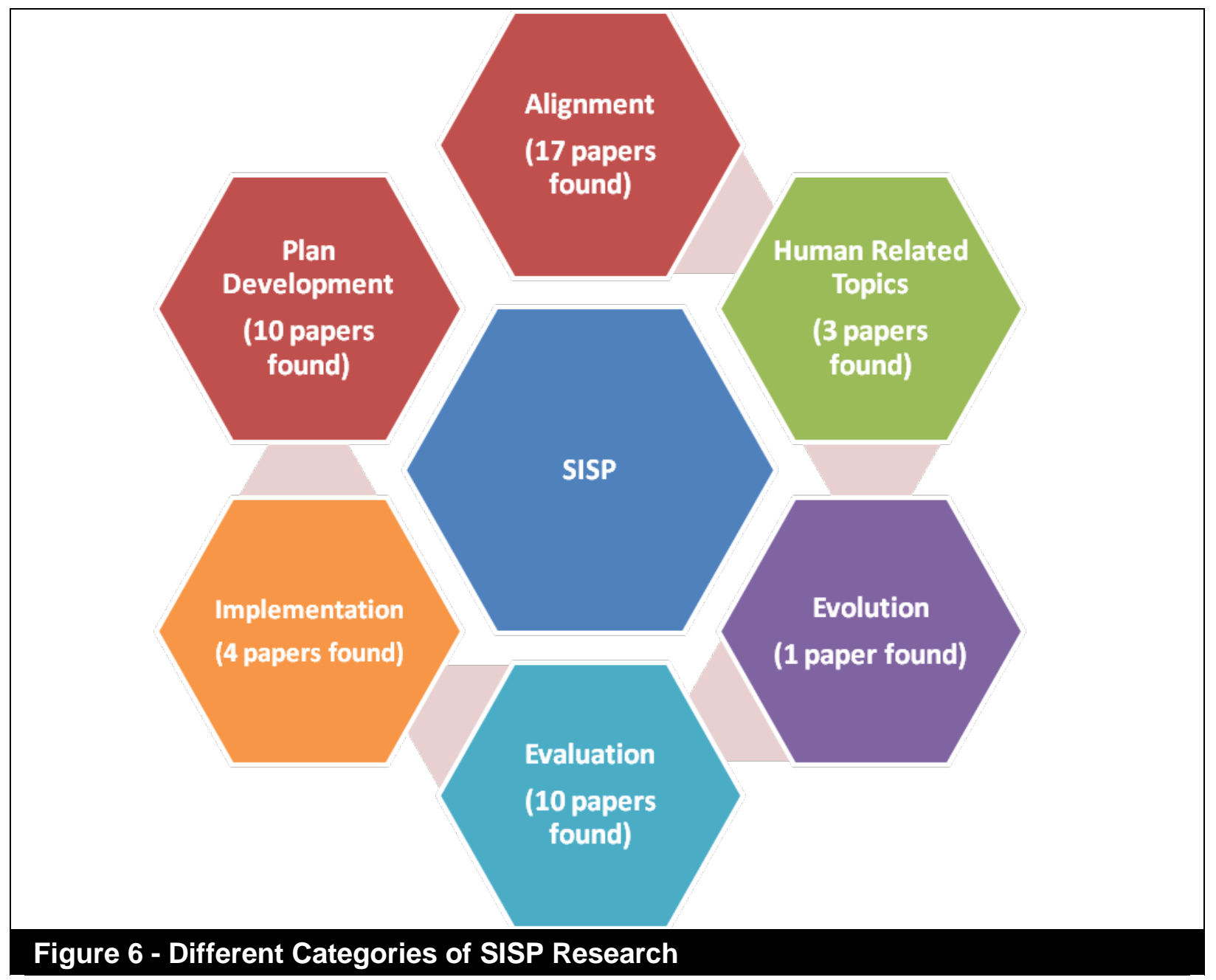

\section{Implementation}

These papers provide some methods for implementing the SISP most effectively in the organization. Four papers in this category cover both empirical research and case studies. Schneberger (2004) introduced the implementation of e-service strategy in the financial sector in Europe. The paper covers the background, development and implementation of the strategy in an organization.

The challenges of implementation are another topic which was highlighted in this stream. Research by Teubner (2007) is an example which targeted the barriers of implementing methodologies in the field of SISP and mainly focused on the gap between academic research and actual practice in the field. This paper suggests "translating the academic discussion into practical recommendation", considering contextual factors of the firm, and identification of appropriate roles as factors that may help both academics and practitioners to overcome the gap.

Finally Krell and Matook (2009) investigated "Mandatory Investments" (investments which are made compulsory by governments) and study which method could be most beneficial in handling this issue. The research suggests that firms use the formal methodologies across the entire company (not specific departments) when IS investments are mandatory for them. 


\begin{tabular}{|l|l|l|}
\hline \multicolumn{2}{|c|}{ Table 4-Dependant /independent factors in study of SISP effectiveness } \\
\hline Reference & Independent factors & Dependant factors \\
\hline $\begin{array}{l}\text { (Wang and Tai, } \\
\text { 2003) }\end{array}$ & $\begin{array}{l}\text { Formalization, } \\
\text { Centralization }\end{array}$ & $\begin{array}{l}\text { Improvement in capabilities, Fulfilment } \\
\text { of objectives }\end{array}$ \\
\hline $\begin{array}{l}\text { (Kearns and Lederer, } \\
\text { 2004) }\end{array}$ & $\begin{array}{l}\text { environmental uncertainty, } \\
\text { information intensity }\end{array}$ & The use of IT for competitive advantage \\
\hline $\begin{array}{l}\text { (Newkirk awer, 2006) } \\
\text { Ledereness, }\end{array}$ & $\begin{array}{l}\text { strategic Alignment, analysis, cooperation } \\
\text { situation analysis, strategy } \\
\text { conception, strategy } \\
\text { formulation, } \\
\text { implementation }\end{array}$ & \\
\hline (Newkirk et al., 2008) & business and IT change & Alignment with business strategies \\
\hline (Bechor et al., 2010) & $\begin{array}{l}\text { SISP approach, SISP } \\
\text { context }\end{array}$ & $\begin{array}{l}\text { Improvement in capabilities, Fulfilment } \\
\text { of objectives }\end{array}$ \\
\hline
\end{tabular}

\section{Evaluation}

Papers in this category aimed to answer the question of how the effectiveness and success of SISP could be measured or improved. In fact this category of research is one in which most of researchers use positivist cause-effect research models which are usually evaluated with quantitative methods.

Some factors that have been found to have an effect on the success of SISP are formalization and centralization (Wang and Tai, 2003), environmental uncertainty and information intensity (Kearns and Lederer, 2004), strategic awareness, situation analysis, strategy conception, strategy formulation and implementation (Newkirk and Lederer, 2006), decentralization and alignment (Mohdzain and Ward, 2007), business and IT change (Newkirk et al., 2008), SISP approach (in terms of strategy execution, technology potential, service level, competitive potential) and SISP context (in terms of dynamism, hostility, heterogeneity, business strategy and IT importance) (Bechor et al., 2010).

The other important topic in this category is the authors' idea about the definition of success or effectiveness of SISP. Searching the related literature, we found several different notions; Wang and Tai (2003) introduced "Improvements in planning capability" and "Fulfilment of planning objectives" as measures for planning effectiveness but Kearns and Lederer (2004) describe the use of IT for competitive advantage as the measure of success. Newkirk and Lederer (2006) have provided more details on their model for evaluation of SISP success. Their factors include alignment (with business strategy), analysis (outcome of the internal analysis), cooperation (stakeholders' agreement) and capabilities (which refers to the development of new systems). Newkirk et al. (2008) also use alignment with the business strategies as an effectiveness measure and finally Bechor et al. (2010) introduce two measures for evaluating the success of SISP which are improvement in IS related capabilities (capabilities) and meeting the planning objectives of planning (effectiveness).

On the other hand, these papers also evaluate the impact of SISP on organizational effectiveness. Bulchand-Gidumal and MeliánGonzález (2011), for example, studied the impact of IT expenditure on organizational performance. Their study indicates that strategic planning for IT positively influences the performance of an organization by retention of human and physical IT resources. Table 4 shows some of dependant I independent factors of studies in this category. 


\section{Alignment}

Research in this category investigates how SISP could be aligned with organizational strategy. In some review papers, alignment is named as an independent research stream (Chen et al., 2010) but in view of the many similarities and interrelations we considered it as a category of SISP research

The 17 papers which we found in this category concern topics such as the impact of strategic IS decisions on business strategies, detailed strategic plans for alignment, the effect of planning on alignment, the alignment in different contexts, such as interorganizational relationships, specific industries, and developing countries.

For example Peak et al. (2005) introduce a process for aligning IT resources and business objectives based on Critical Success Factors (CSFs). Rathnam et al. (2004) also studied the gap between IT strategy and business strategy and provided some recommendations for improving the alignment. Their paper suggests business architecture and a centralized IT department as possible solution for improving the gap between those strategies.

Like other categories, we also found several case studies which addressed the alignment in a variety of contexts. Premkumar et al. (2005) use Galbraith's information processing theory to study the alignment in the context of inter-organizational relationships. Fairbank et al. (2006) use the same concept to analyse how organizations can benefit from the fit to increase their organizational performance. Finally Yayla and $\mathrm{Hu}$ (2012) studied the contextual factors of developing countries in strategic alignment. Their study mainly focuses on uncertainty as a contextual factor and confirms the positive effect of alignment between IT and business strategies on the performance of the organization.

\section{Human Related Ttopics}

We found three papers in the literature which concerned the role of people in SISP. The main themes of this category include adoption, the impact of job characteristics on the effectiveness of SISP and support.

Byrd et al. (2006) for example, studied the effect of senior IT leadership and SISP on the implementation of the IS infrastructure. This study defines IT leadership in the context of the importance of the $\mathrm{ClO}$ and the presence of a varied IS advisory committee and provides empirical evaluation of the moderator role of SISP in the relationship between this support and the three aspects of IS implementation, which are technology integration, application functionality and data integration.

Scott (2005) also investigated different planning and alignment approaches with respect to the role of IT managers and other personnel and recommends best practices for improvement. Another study also investigates autonomy and procedural justice and concludes that these job characteristics positively influence the effectiveness of SISP (Mirchandani and Lederer, 2012).

\section{Evolution}

The last theme of the research in the field of SISP, which we found in only one paper, is the evolution of SISP. Here the research question is: how can SISP evolve during different levels of organizational evolution and how should it provide answers to the new contextual aspects and challenges of the organization over time?

This paper investigates the evolution of planning systems in terms of level of formalization, comprehensiveness, top-down flow, control focus, participation and consistency, and studies the effect of this evolution on planning effectiveness (Grover and Segars, 2005). The result is depicted in a three-stage model that shows the evolution of planning from the preliminary stage through the evolving and finally to the mature stage.

Table 5 presents different categories of paper in the field of SISP as well as a brief definition and major findings of each category. 


\begin{tabular}{|c|c|c|c|}
\hline Category & $\begin{array}{l}\text { Main } \\
\text { Research } \\
\text { Question } \\
\end{array}$ & $\begin{array}{l}\text { Papers within the } \\
\text { category }\end{array}$ & Major findings \\
\hline Alignment & $\begin{array}{l}\text { How could } \\
\text { SISP be } \\
\text { aligned with } \\
\text { organization } \\
\text { al strategy? }\end{array}$ & $\begin{array}{l}\text { (Fairbank et al., 2006; } \\
\text { Grant, 2003; Kearns } \\
\text { and Sabherwal, 2006; } \\
\text { Kearns, 2005; Peak et } \\
\text { al., 2005; Premkumar } \\
\text { et al., 2005; Qing and } \\
\text { Huang, 2006; Rathnam } \\
\text { et al., 2004; Slaughter } \\
\text { et al., 2006; Thorogood } \\
\text { et al., 2004; Gregor et } \\
\text { al., 2007; Tallon, 2007; } \\
\text { Chen et al., 2010; } \\
\text { Chen, 2010; Tallon, } \\
\text { 2010; Valorinta, 2011; } \\
\text { Yayla and Hu, 2012) }\end{array}$ & $\begin{array}{l}\text { Positive effect of alignment } \\
\text { between IT and business } \\
\text { strategies on the performance of } \\
\text { organization } \\
\text { Contextual factors can influence } \\
\text { alignment }\end{array}$ \\
\hline $\begin{array}{l}\text { Plan } \\
\text { development }\end{array}$ & $\begin{array}{l}\text { What are } \\
\text { the tools, } \\
\text { techniques } \\
\text { and best } \\
\text { practices for } \\
\text { developing } \\
\text { SISP? }\end{array}$ & $\begin{array}{l}\text { (Al-Jaghoub and } \\
\text { Westrup, 2003; Brigl et } \\
\text { al., 2005; Druckenmiller } \\
\text { and Acar, 2009; Dufner } \\
\text { et al., 2003; Gao, 2005; } \\
\text { Kahraman et al., 2007; } \\
\text { Klein and Krcmar, } \\
\text { 2006; Newkirk et al., } \\
\text { 2003; Peffers et al., } \\
\text { 2003; Wagner, 2004) }\end{array}$ & $\begin{array}{l}\text { Case studies which address } \\
\text { challenges and difficulties of } \\
\text { development } \\
\text { Methodologies for better } \\
\text { communication and wider } \\
\text { participation in development }\end{array}$ \\
\hline Evaluation & $\begin{array}{l}\text { How could } \\
\text { the } \\
\text { effectivenes } \\
\text { s and } \\
\text { success of } \\
\text { SISP be } \\
\text { measured } \\
\text { or } \\
\text { improved? }\end{array}$ & $\begin{array}{l}\text { (Bechor et al., 2010; } \\
\text { Bossen, 2007; } \\
\text { Bulchand-Gidumal and } \\
\text { Melián-González, 2011; } \\
\text { Cohen, 2008; Kearns } \\
\text { and Lederer, 2004; } \\
\text { Mohdzain and Ward, } \\
\text { 2007; Newkirk and } \\
\text { Lederer, 2006, 2007; } \\
\text { Newkirk et al., 2008; } \\
\text { Wang and Tai, 2003) }\end{array}$ & $\begin{array}{l}\text { Various factors may help the } \\
\text { success of SISP in organization } \\
\text { Strategic planning for IT/IS helps } \\
\text { the performance of firm }\end{array}$ \\
\hline Implementation & $\begin{array}{l}\text { How could } \\
\text { SISP be } \\
\text { implemente } \\
d \text { in the } \\
\text { most } \\
\text { effective } \\
\text { way in an } \\
\text { organization }\end{array}$ & $\begin{array}{l}\text { (Choudrie et al., 2003; } \\
\text { Krell and Matook, 2009; } \\
\text { Schneberger, 2004; } \\
\text { Teubner, 2007) }\end{array}$ & $\begin{array}{l}\text { Recommendations for remove the } \\
\text { gap between academic research } \\
\text { and actual practice } \\
\text { Contextual factors can help the } \\
\text { implementation }\end{array}$ \\
\hline
\end{tabular}




\begin{tabular}{|c|c|c|c|}
\hline Category & $\begin{array}{l}\text { Main } \\
\text { Research } \\
\text { Question }\end{array}$ & $\begin{array}{l}\text { Papers within the } \\
\text { category }\end{array}$ & Major findings \\
\hline & $?$ & & \\
\hline $\begin{array}{l}\text { Human related } \\
\text { topics }\end{array}$ & $\begin{array}{l}\text { What is the } \\
\text { role of } \\
\text { people in } \\
\text { SISP? }\end{array}$ & $\begin{array}{l}\text { (Byrd et al., 2006; } \\
\text { Mirchandani } \\
\text { Lederer, 2012; Scott, } \\
\text { 2005) }\end{array}$ & $\begin{array}{l}\text { Central role of IT leadership in } \\
\text { SISP }\end{array}$ \\
\hline Evolution & $\begin{array}{l}\text { How can } \\
\text { SISP evolve } \\
\text { over time? }\end{array}$ & $\begin{array}{l}\text { (Grover and Segars, } \\
\text { 2005) }\end{array}$ & $\begin{array}{l}\text { Three stage model for evolution } \\
\text { of SISP in organizations }\end{array}$ \\
\hline
\end{tabular}

\section{Used Research Methods}

We also considered approaches that were used in the SISP literature and classified them into three groups: quantitative, qualitative and other approaches (literature review, etc.). Figure 7 illustrates the frequency of each approach in the literature. As depicted in this figure, quantitative methods have been the dominant methods in the literature.

In terms of research technique, a variety of methods is observable. These are questionnaire, case study, literature review and interview. Table 6 compares different categories and research approaches. As depicted in Figure 7, here again the questionnaire, which is usually a quantitative approach, is the dominant method.

\section{Theoretical Foundation}

Other than above mentioned dimensions, we paid attention to theoretical foundation of the extracted papers. To do this we paid attention to research models in the papers and paid attention to theories, models and tools which have been used to develop research models and hypotheses. We found verity of theories and models with their roots in management science, strategic management and information systems which were used in different papers. Table 7 includes information on the used theories.

\section{Table 6-Comparing research topics and research approaches}

\begin{tabular}{|l|c|c|c|}
\hline Topic & Quantitative & Qualitative & Other methods \\
\hline Alignment & $\square$ & $\square$ & $\square$ \\
\hline Plan development & $\square$ & $\square$ & $\square$ \\
\hline Evaluation & $\square$ & $\square$ & - \\
\hline Implementation & $\square$ & - & - \\
\hline Human related topics & $\square$ & - & $\square$ \\
\hline Evolution & $\square$ & - & - \\
\hline
\end{tabular}




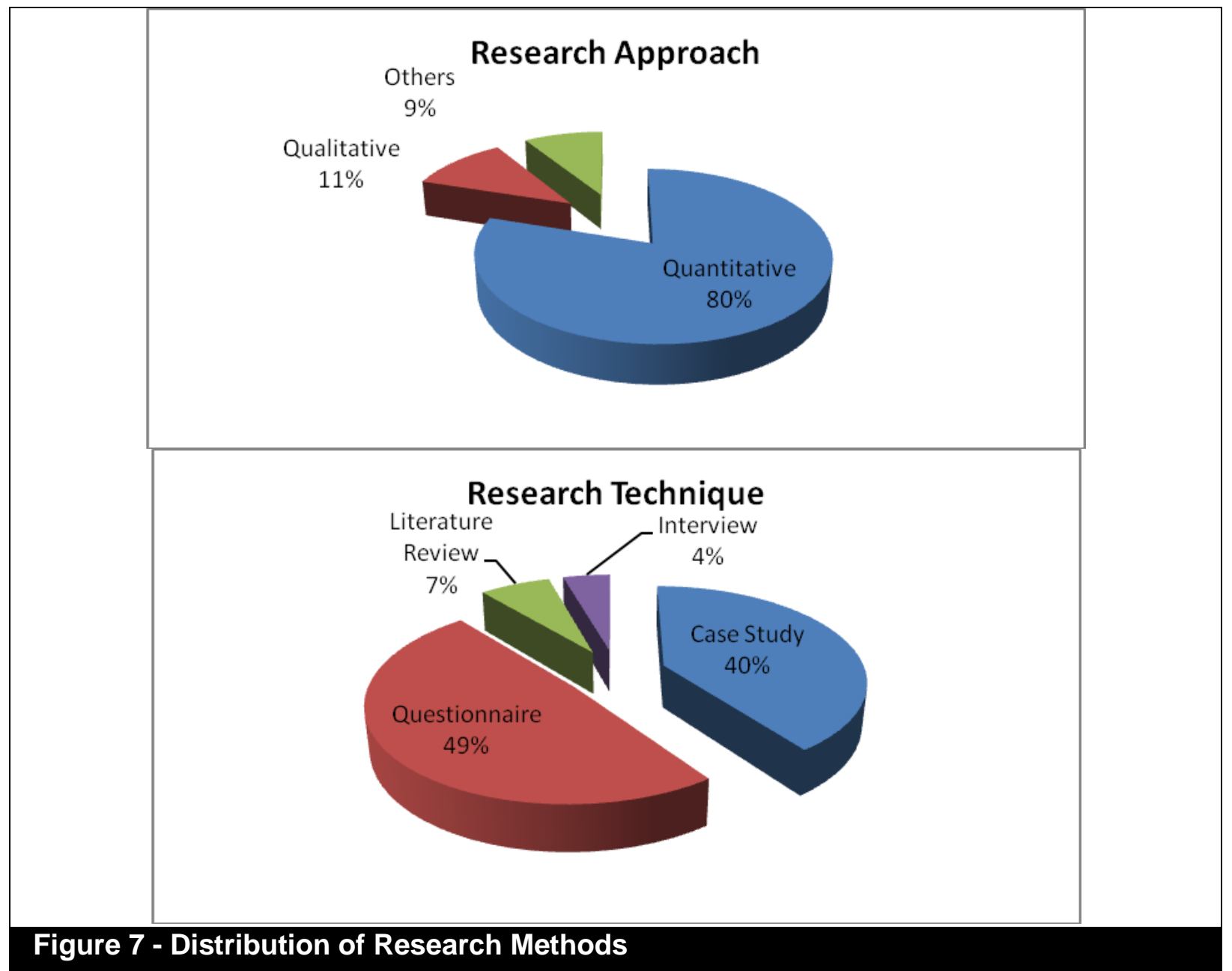

\section{Discussion}

In this paper we attempted to provide an overview of SISP literature over the last ten years. To do this, we selected 45 related papers from 12 most influential IS journals and, after analysis of their content, provided a classification of the focus, context, main categories and research approaches.

The results indicate that most of the researchers in the field focused on the context and tools of SISP and paid less attention to the people and the impact. Also, in terms of the research context, most of their attention was paid to firms.

\section{Implications for Researchers}

New researchers who are motivated to conduct studies in SISP can benefit from this paper by specifying their work within the provided frameworks. This study may also help them to recognize some gaps in the literature.

Based on reviewing the related literature in the top ranking journals, it could be concluded that most of the researchers tend to focus on the context and tools in SISP and that people and impact were subject to less attention in general. On the other hand, similar statistics can be seen in reviewing literature topics in which "implementation", "human related topics" and "evolution" are less popular with researchers.

In accordance with our analysis of the related literature, we highly recommend further 
research focuses on the role of the personnel and the evolution process for SISP. Although these two categories are popular in basic research in the field of strategic management, the IS stream has paid less attention to them up to now. Qualitative and mixed methods are becoming increasingly popular in social science and especially strategic management literature. For example, Molina-Azorin (2012) through survey of papers in the Strategic Management Journal from 1980 to 2006 has concluded that "....all types of mixed methods articles tend to have a higher number of citations than the group of mono-method studies...".We recognize that qualitative and mixed methods research may also be more beneficial to the related body. These techniques may better help researchers to identify different aspects of SISP and the conception of different stakeholders (not only CEOs and CIOs) of the topic.

\section{Future Research}

Having established the field and summarized the existing research, current section provides some recommendations for future research in each topic. Although our review has been limited to 12 top ranked journals, this study of leading research still helps to identify gaps in the literature and opportunities for further research.

\section{Plan development}

The gap between theory and practice may indicate the lack of appropriate methods which could be compatible with the conditions of firms in different sectors and countries. As Teubner (2007) has shown, paying attention to contextual factors may resolve the issue. For this reason developing new methods of planning which are based on specific contexts is highly recommended by our study.

\section{Implementation}

We found limited case studies in the implementation of SISP. Future research can address challenges of SISP implementation in many other industries including health, education, and the manufacturing companies.

Relating this category with development and evaluation may also result in a better understanding of the appropriate ways of implementing each planning method and the effectiveness of the solutions for development and implementation.

\section{Evaluation}

In our study of papers in this category, we found a variety of factors which were cited as influencing factors or measures for success of SISP. However our study shows that some types of factors have been giver less

\begin{tabular}{|c|c|c|}
\hline Reference & Used Theory I Model & Origin of theory I Model \\
\hline $\begin{array}{l}\text { (Al-Jaghoub and Westrup, } \\
\text { 2003) }\end{array}$ & competition state theory & Management \\
\hline (Choudrie et al., 2003) & stakeholder theory & Strategic management \\
\hline (Newkirk et al., 2003) & $\begin{array}{l}\text { Information processing } \\
\text { theory }\end{array}$ & Information systems \\
\hline (Kearns and Lederer, 2004) & $\begin{array}{l}\text { Stages of growth or } \\
\text { evolution models }\end{array}$ & Information systems \\
\hline (Byrd et al., 2006) & IS Infrastructure Model & Information systems \\
\hline $\begin{array}{l}\text { (Kearns and Sabherwal, } \\
2006)\end{array}$ & $\begin{array}{l}\text { knowledge-based theory of } \\
\text { the firm }\end{array}$ & Management \\
\hline (Qing and Huang, 2006) & $\begin{array}{l}\text { the balanced scorecard } \\
\text { theory of business }\end{array}$ & Strategic management \\
\hline $\begin{array}{l}\text { (Bechor et al., } 2010 ; \\
\text { Slaughter et al., 2006) }\end{array}$ & contingency theory & Management \\
\hline (Tallon, 2007) & resource-based view & Management \\
\hline (Cohen, 2008) & Upper echelons theory & Management \\
\hline
\end{tabular}


attention. For example social factors like trust, integrity, quality of communication and participation are not found in the studied papers.

However, there is a lack of theories in this category and we call future research to develop specific theories for evaluation of success using grounded theory method. Another recommendation for future research is systematic and comprehensive reviews in this category which may result in identifying further gaps and maybe a meta-analysis of the studied factors.

\section{Alignment}

Although several papers in our pool have studied different aspects of alignment, several topics have not been addressed in the previous studies. Factors that may result in better alignment are less explained in the literature. This factors may be planning process and methods, attributes of IS/IT in organization and organizational or business factors.

Alignment tools and methods are another topic which could be studied in detail in future research. Future researchers specially can work on aspects like tying these methods with current planning methods and evaluation of them in terms of their organizational outcome.

\section{Human related topics}

Nixon and Burns in a synthesis of different research, study the evolution of strategic management. They associate the post 2000 era with terms like "knowledge workers", "networks", "cross cultural communication", and so on (Nixon and Burns, 2012). Unlike the trend in the basic literature of strategic management, SISP literature has ignored this stream. Topics like adoption of SISP by different stakeholders, team developing, stakeholder involvement, support of different roles, and so on, could be addressed in depth in future research.

\section{Evolution}

The evolution of SISP is another important topic which could be classified as a "research gap" in SISP. Mintzberg (1994) refers to a fallacy premise of strategic planning according to which "the world is supposed to hold still while a plan is being developed and then stay on the predicted course while that plan is being implemented". The same problem also exists in SISP and the question of "how should SISP adapt with the dynamic changes of the organizational context?" should be answered with the evolution topic.

\section{Implications for Practitioners}

The work of Teubner (2007) confirms that "practitioners largely ignore academic literature and do not use it in support of their SISP endeavours". The reason for this could be the complexity of the research which makes practitioners confused in defining their problems and finding the research that exactly provides the solutions to their specific problems. Business owners and $\mathrm{ClOs}$ as well as IS/IT managers may use this paper in order to find the different areas of study that may benefit their business and organizational decisions.

The plan development area may inform practitioners about the latest innovations in the tools and techniques for the development of SISP as well as best practices in the area. With this topic, good advice is provided by Newkirk et al. (2003) which indicates that "both too much and too little implementation planning may hinder SISP success" because " too little could produce implementation plans with insufficient detail to permit their successful execution. Too much could complicate, delay, or otherwise impede implementation".

The implementation area, on the other hand, is similarly beneficial for people who seek advice on the implementation phase of SISP. The surprising finding in this topic may be the result of the work of Krell and Matook (2009) which indicates that many Australian companies have achieved competitive advantage through their investment in IS, 
A Systematic Literature Review on Strategic Information Systems Planning / Amrollahi et al.

which has been a government imposed obligation. This may motivate IS managers to consider government regulation as a strategic opportunity.

Evaluation of SISP may inform practitioners about the effectiveness of their efforts as well as how to increase them. Newkirk and Lederer (2006), for example, studied the role of uncertainty in the success of SISP. This research suggests that practitioners avoid putting their effort only into the strategic conception phase because this phase has not predicted success in any environmental dimension.

The alignment topic is also an important matter which relates to leveraging SISP to reach organizational goals. For example, Chen (2010) introduces an instrument by which the alignment in the company can be assessed and also the challenges they face in improving IS planning and management is presented.

While SISP involves many transactions with personnel at different levels, human related issues should be considered in all stages of SISP. Lack of consideration of these factors may result in the process of SISP facing dramatic challenges. Among the few papers that we found on this topic, the work of Mirchandani and Lederer (2012) is a good example which warns the parent-company managers of big firms of the role and autonomy of subsidiary-company managers in SISP.
Finally, evolution is considered to be an important topic in SISP. With this stream of research, practitioners can find ways to evolve the plan according to the dynamic environments of their business and IT/IS needs. The only paper with this topic suggests that firms "assess their current state of SISP through which they can gain insight into the direction of change needed".

\section{Conclusion}

This paper provides different categorizations of the focus, context, topics and methods of SISP research. Our study reveals that the contexts of firms and topics, such as alignment and evaluation, and the development of SISP have been subjected to more interest in the literature, than others, such as implementation, human related topics and evolution. The framework and discussion about each element given above can provide an overview of the SISP research for new researchers in the field or help others to recognize the research gaps. Practitioners also may benefit from this study by understanding the proper research stream and/or research that may help them resolve their specific business problems. 


\section{References}

Al-Jaghoub, S., \& Westrup, C., (2003). Jordan and ICT-led development: towards a competition state? Information Technology \& People, 16(1), pp.93-110.

Andersen, A., (1988). Method/1 User Manual. Arthur Andersen \& Co.

Bechor, Tamir, Neumann, Seev, Zviran, Moshe, \& Glezer, Chanan, (2010). A contingency model for estimating success of strategic information systems planning. Information \& Management, 47(1), pp.17.

Bossen, Claus, (2007). Test the artefactDevelop the organization: The implementation of an electronic medication plan. International Journal of Medical Informatics, 76(1), pp.1321.

Brigl, B., Ammenwerth, E., Dujat, C., Gräber, S., Große, A., Häber, A., . . Winter, A., (2005). Preparing strategic information management plans for hospitals: a practical guideline: SIM plans for hospitals: a guideline. International Journal of Medical Informatics, 74(1), pp.51-65.

Bulchand-Gidumal, Jacques, \& MeliánGonzález, Santiago, (2011). Maximizing the positive influence of IT for improving organizational performance. The Journal of Strategic Information Systems, 20(4), pp.461478.

Byrd, Terry Anthony, Lewis, Bruce R., \& Bradley, Randy V., (2006). IS infrastructure: the influence of senior it leadership and strategic information systems planning. Journal of Computer Information Systems, 47(1), pp.101-113.

Charles Wiseman, Ian C. MacMillan, (1984). Creating competitive weapons from information systems. Journal of Business Strategy, 5(2), pp.42-49.
Chen, Daniel Q., Mocker, Martin, Preston, David S., \& Teubner, Alexander, (2010). Information systems strategy: reconceptualization, measurement, and implications. MIS Quarterly, 34(2), pp.233-238.

Chen, Leida, (2010). Business-IT alignment maturity of companies in China. Information \& Management, 47(1), pp.9-16.

Choudrie, J., Papazafeiropoulou, A., \& Lee, H., (2003). A web of stakeholders and strategies: A case of broadband diffusion in South Korea. Journal of Information Technology, 18(4), pp.281-290.

Cohen, Jason F., (2008). Contextual determinants and performance implications of information systems strategy planning within South African firms. Information \& Management, 45(8), pp.547-555.

Holland Systems Corporation. (1986). \#M0154-04861986. Ann Arbor, Michigan.

Doherty, N. F., Marples, C. G., \& Suhaimi, A., (1999). The relative success of alternative approaches to strategic information systems planning: an empirical analysis. The Journal of Strategic Information Systems, 8(3), pp.263-283.

Druckenmiller, D. A., \& Acar, W., (2009). An agent-based collaborative approach to graphing causal maps for situation formulation. Journal of the Association of Information Systems, 10(3), pp.221-251.

Dufner, Donna, Holley, Lyn M, \& Reed, BJ, (2003). Strategic information systems planning and US county government. Communications of the Association for Information Systems, 11(1), pp.13.

Earl, M. J. (2003). Approaches to Information Systems Planning-Experiences in Strategic Information Systems Planning. In Strategic Information 
A Systematic Literature Review on Strategic Information Systems Planning / Amrollahi et al.

Management: Challenges and Strategies in Managing Information Systems: Taylor and Francis.

Earl, M.J., (1989). Management Strategies for Information Technology: Prentice Hall.

Earl, M.J., (1993). Experiences in strategic information systems planning. MIS Quarterly, 17(1), 1-24.

Excellence in Research for Australia (ERA) (2010). Retrieved 15 Jan 2013, from http://www.arc.gov.au/era/

Fairbank, J. F., Labianca, G., Steensma, H. K., \& Metters, R., (2006). Information processing design choices, strategy, and risk management performance. Journal of Management Information Systems, 23(1), 293-319.

Gao, P., (2005). Using actor-network theory to analyse strategy formulation. Information Systems Journal, 15(3), 255-275.

Ghapanchi, Amir Hossein, \& Aurum, Aybuke, (2011). Antecedents to IT personnel's intentions to leave: A systematic literature review. Journal of Systems and Software, 84(2), 238-249.

Grant, G. G., (2003). Strategic alignment and enterprise systems implementation: The case of Metalco. Journal of Information Technology, 18(3), 159175.

Gregor, S., Hart, D., \& Martin, N., (2007). Enterprise architectures: Enablers of business strategy and IS/IT alignment in government. Information Technology and People, 20(2), 96120.

Grover, Varun, \& Segars, Albert H., (2005). An empirical evaluation of stages of strategic information systems planning: patterns of process design and effectiveness. Information \& Management, 42(5), 761-779.

Kahraman, C., Demirel, N. Ç, \& Demirel, T., (2007). Prioritization of e-Government strategies using a SWOT-AHP analysis: The case of Turkey. European Journal of Information Systems, 16(3), 284-298.

Kearns, G. S., \& Sabherwal, R., (2006). Strategic alignment between business and information technology: A knowledge-based view of behaviors, outcome, and consequences. Journal of Management Information Systems, 23(3), 129-162.

Kearns, Grover S., (2005). An electronic commerce strategic typology: insights from case studies. Information \& Management, 42(7), 1023-1036.

Kearns, Grover S., \& Lederer, Albert L., (2004). The impact of industry contextual factors on IT focus and the use of IT for competitive advantage. Information \& Management, 41(7), 899-919.

Kitchenham, Barbara, (2004). Procedures for performing systematic reviews. Keele, UK, Keele University, 33, 2004.

Kitchenham, Barbara A, \& Charters, Stuart, (2007). Guidelines for performing systematic literature reviews in software engineering.

Klein, A., \& Krcmar, H., (2006). DCXNET: Etransformation at DaimlerChrysler. Journal of Information Technology, 21(1), 52-65.

Kleis, L., Chwelos, P., Ramirez, R.V., \& Cockburn, I., (2012). Information technology and intangible output: The impact of IT investment on innovation productivity. Information Systems Research, 23(1), 42-59.

Krell, Katharina, \& Matook, Sabine, (2009). Competitive advantage from mandatory investments: An empirical study of Australian firms. The Journal of Strategic Information Systems, 18(1), 31-45.

Lederer, A.L., \& Sethi, V., (1980). The implementation of strategic information systems planning 
methodologies. MIS Quarterly, pp.445-461.

Luftman, Jerry, \& Ben-Zvi, Tal, (20110. Key Issues for IT Executives 2011: Cautious Optimism in Uncertain Economic Times. MIS Quarterly Executive, 10(4), pp.203-212.

Martin, J., (1982). Strategic Data-Planning Methodologies Prentice Hall. Englewood Cliffs, NJ.

Mintzberg, Henry, (1994). The fall and rise of strategic planning. Harvard business review, 72, pp.107-107.

Mirchandani, D. A., \& Lederer, A. L., (2012). Autonomy and procedural justice in strategic systems planning. Information Systems Journal.

Mohdzain, Mohdzaher B., \& Ward, John M., (2007). A study of subsidiaries' views of information systems strategic planning in multinational organisations. The Journal of Strategic Information Systems, 16(4), pp.324-352.

Molina-Azorin, Jose F, (2012). Mixed Methods Research in Strategic Management Impact and Applications. Organizational Research Methods, 15(1), pp.33-56.

Newkirk, Henry E., \& Lederer, Albert L., (2006). The effectiveness of strategic information systems planning under environmental uncertainty. Information \& Management, 43(4), pp.481-501.

Newkirk, Henry E., \& Lederer, Albert L., (2007). The effectiveness of strategic information systems planning for technical resources, personnel resources, and data security in environments of heterogeneity and hostility. Journal of Computer Information Systems, 47(3), pp.34-44.

Newkirk, Henry E., Lederer, Albert L., \& Johnson, Alice M., (2008). Rapid business and IT change: drivers for strategic information systems planning?
European Journal of Information Systems, 17(3), pp.198-218.

Newkirk, Henry E., Lederer, Albert L., \& Srinivasan, Cidambi, (2003). Strategic information systems planning: too little or too much? The Journal of Strategic Information Systems, 12(3), pp.201228.

Nixon, Bill, \& Burns, John, (2012). The paradox of strategic management accounting. Management Accounting Research, 23(4), pp.229-244.

Pant, S., \& Hsu, C. (1995), Strategic information systems planning: a review. Paper presented at the Information Resources Management Association International Conference.

Pant, S., \& Hsu, C., (1999). An integrated framework for strategic information systems planning and development. Information Resources Management Journal (IRMJ), 12(1), pp.15-25.

Peak, Dan, Guynes, C. Steve, \& Kroon, Verlyn, (2005). Information Technology Alignment Planning-a case study. Information \& Management, 42(5), pp.635-649.

Peffers, K., Gengler, C. E., \& Tuunanen, T., (2003). Extending critical success factors methodology to facilitate broadly participative information systems planning. Journal of Management Information Systems, 20(1), pp.51-85.

Porter, M.E., (1998). Competitive advantage: Creating and sustaining superior performance: Free press.

Premkumar, G., Ramamurthy, K., \& Saunders, C. S., (2005). Information processing view of organizations: An exploratory examination of fit in the context of interorganizational relationships. Journal of Management Information Systems, 22(1), pp.257294. 
Qing, Hu, \& Huang, C. Derrick, (2006). Using the balanced scorecard to achieve sustained it-business alignment: a case study. Communications of AIS, 15, pp.2-45.

Rackoff, Nick, Wiseman, Charles, \& Ullrich, Walter A., (1985). Information Systems for Competitive Advantage: Implementation of a Planning Process. MIS Quarterly, 9(4), pp.285-294.

Rathnam, R. G., Johnsen, Justin, \& Wen, H. Joseph, (2004). Alignment of business strategy and it strategy: a case study of a fortune 50 financial services company. Journal of Computer Information Systems, 45(2), pp.1-8.

Rockart, J.F., (1979). Chief executives define their own data needs. Harvard business review, 57(2), pp.81-93.

Sabherwal, R., \& Chan, Y.E., (2001). Alignment between business and IS strategies: A study of prospectors, analyzers, and defenders. Information Systems Research, 12(1), pp.11-33.

Schneberger, S. L., (2004). STATER NV: Eservicing strategies. Journal of Information Technology, 19(2), pp.108-116.

Scott, George M., (2005). Still Not Solved: The Persistent Problem of IT Strategic Planning. Communications of AIS, 14, pp.904-936.

Slaughter, Sandra A., Levine, Linda, Ramesh, Balasubramaniam, Pries-Heje, Jan, \& Baskerville, Richard, 2006. ALIGNING SOFTWARE PROCESSES WITH STRATEGY. MIS Quarterly, 30(4), pp.891-918.

Synnott, W.R., \& Gruber, W.H., (1981). Information resource management: opportunities and strategies for the 1980s: John Wiley \& Sons, Inc.

Tallon, P. P., (2007). A process-oriented perspective on the alignment of information technology and business strategy. Journal of Management
Information Systems, 24(3), pp.227268.

Tallon, P. P., (2010). A service science perspective on strategic choice, IT, and performance in U.S. banking. Journal of Management Information Systems, 26(4), pp.219-252.

Teubner, R. A., (2007). Strategic information systems planning: A case study from the financial services industry. The Journal of Strategic Information Systems, 16(1), pp.105-125.

Thorogood, A., Yetton, P., Vlasic, A., \& Spiller, J., (2004). Raise your glasses - The water's magic! Strategic IT at SA Water: A case study in alignment, outsourcing and governance. Journal of Information Technology, 19(2), pp.130-139.

Valorinta, M., (2011). IT alignment and the boundaries of the IT function. Journal of Information Technology, 26(1), pp.46-59.

Wagner, Christian, (2004). Enterprise strategy management systems: current and next generation. The Journal of Strategic Information Systems, 13(2), pp.105-128.

Wang, Eric T. G., \& Tai, Jeffrey C. F., (2003). Factors affecting information systems planning effectiveness: organizational contexts and planning systems dimensions. Information \& Management, 40(4), pp.287-303.

Yayla, A. A., \& Hu, Q., (2012). The impact of IT-business strategic alignment on firm performance in a developing country setting: Exploring moderating roles of environmental uncertainty and strategic orientation. European Journal of Information Systems, 21(4), pp.373-387.

Zachman, J.A., (1982). Business systems planning and business information control study: a comparison. IBM Systems Journal, 21(1), pp.31-53. 


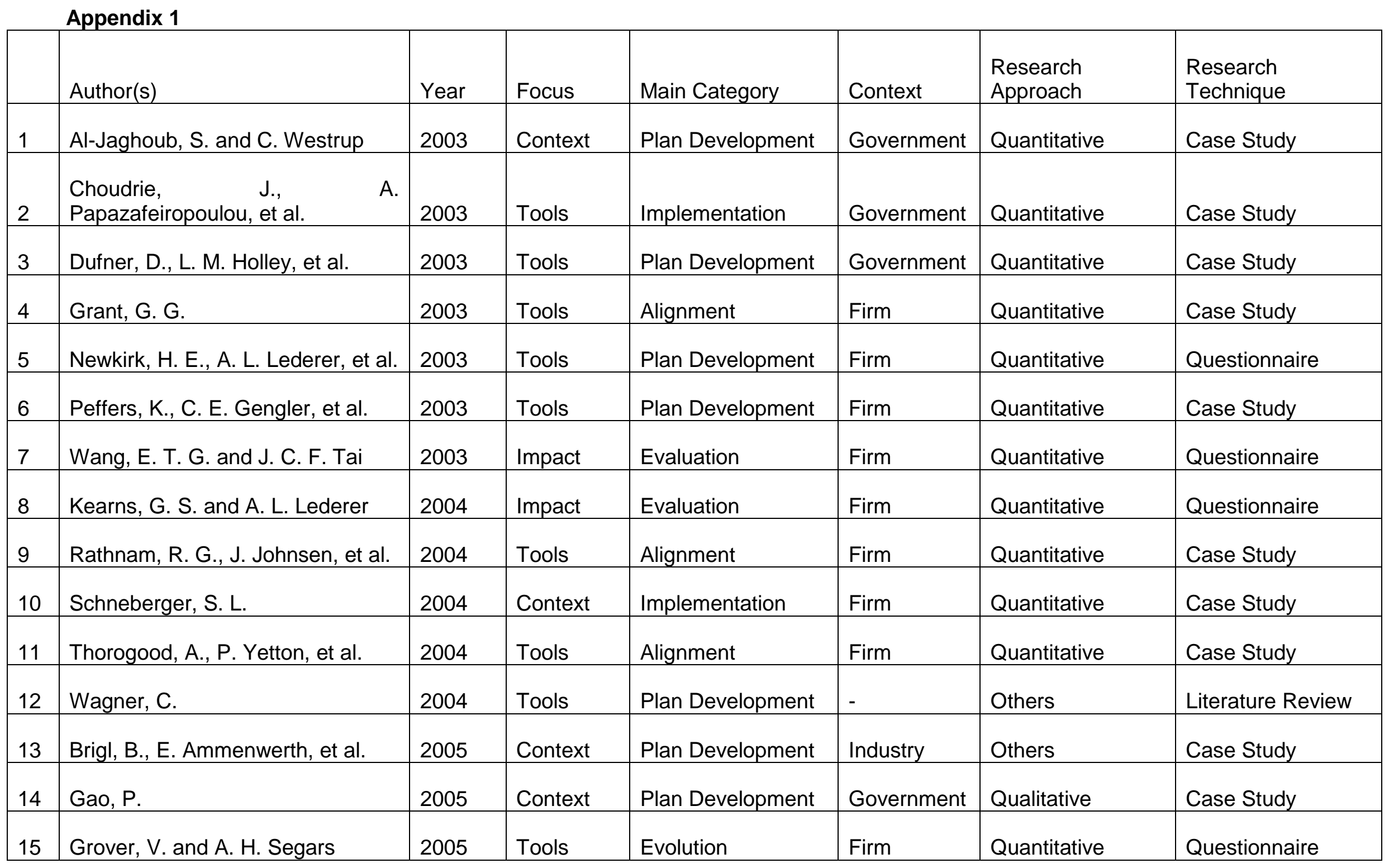


Pacific Asia Journal of the Association for Information Systems, Vol. 5, Iss. 2 [2013], Art. 4

A Systematic Literature Review on Strategic Information Systems Planning / Amrollahi et al.

\begin{tabular}{|c|c|c|c|c|c|c|c|}
\hline & Author(s) & Year & Focus & Main Category & Context & $\begin{array}{l}\text { Research } \\
\text { Approach }\end{array}$ & $\begin{array}{l}\text { Research } \\
\text { Technique }\end{array}$ \\
\hline 16 & Kearns, G. S. & 2005 & Tools & Alignment & Firm & Quantitative & Case Study \\
\hline 17 & Peak, D., C. S. Guynes, et al. & 2005 & Context & Alignment & Firm & Quantitative & Questionnaire \\
\hline 18 & $\begin{array}{l}\text { Premkumar, G., K. Ramamurthy, } \\
\text { et al. }\end{array}$ & 2005 & Context & Alignment & Firm & Quantitative & Questionnaire \\
\hline 19 & Scott, G. M. & 2005 & People & Human related & - & Others & Literature Review \\
\hline 20 & Byrd, T. A., B. R. Lewis, et al. & 2006 & People & Human related & Firm & Quantitative & Questionnaire \\
\hline 21 & Fairbank, J. F., G. Labianca, et al. & 2006 & Context & Alignment & Industry & Quantitative & Questionnaire \\
\hline 22 & Kearns, G. S. and R. Sabherwal & 2006 & Context & Alignment & Firm & Quantitative & Questionnaire \\
\hline 23 & Klein, A. and H. Krcmar & 2006 & Context & Plan Development & Firm & Quantitative & Case Study \\
\hline 24 & Newkirk, H. E. and A. L. Lederer & 2006 & Context & Evaluation & Firm & Quantitative & Questionnaire \\
\hline 25 & Qing, H. and C. D. Huang & 2006 & Tools & Alignment & Firm & Qualitative & Case Study \\
\hline 26 & Slaughter, S. A., L. Levine, et al. & 2006 & Tools & Alignment & Firm & Quantitative & Interview \\
\hline 27 & Bossen, C. & 2007 & Impact & Evaluation & Firm & Qualitative & Case Study \\
\hline 28 & Gregor, S., D. Hart, et al. & 2007 & Tools & Alignment & Firm & Quantitative & Case Study \\
\hline 29 & Kahraman, C., N. Ç. Demirel, et al. & 2007 & Tools & Plan Development & Government & Quantitative & Case Study \\
\hline 30 & Mohdzain, M. B. and J. M. Ward & 2007 & Context & Evaluation & Firm & Qualitative & Interview \\
\hline 31 & Newkirk, H. E. and A. L. Lederer & 2007 & Context & Evaluation & Firm & Quantitative & Questionnaire \\
\hline
\end{tabular}




\begin{tabular}{|c|c|c|c|c|c|c|c|}
\hline & Author(s) & Year & Focus & Main Category & Context & $\begin{array}{l}\text { Research } \\
\text { Approach } \\
\end{array}$ & $\begin{array}{l}\text { Research } \\
\text { Technique }\end{array}$ \\
\hline 32 & Tallon, P. P. & 2007 & Tools & Alignment & Firm & Qualitative & Questionnaire \\
\hline 33 & Teubner, R. A. & 2007 & Context & Implementation & Firm & Quantitative & Case Study \\
\hline 34 & Cohen, J. F. & 2008 & Context & Evaluation & Firm & Quantitative & Questionnaire \\
\hline 35 & Newkirk, H. E., A. L. Lederer, et al. & 2008 & Context & Evaluation & Firm & Quantitative & Questionnaire \\
\hline 36 & Druckenmiller, D. A. and W. Acar & 2009 & Tools & Plan Development & Firm & Quantitative & Case Study \\
\hline 37 & Krell, K. and S. Matook & 2009 & Context & Implementation & Firm & Quantitative & Questionnaire \\
\hline 38 & Bechor, T., S. Neumann, et al. & 2010 & Context & Evaluation & Firm & Quantitative & Questionnaire \\
\hline 39 & Chen, D. Q., M. Mocker, et al. & 2010 & Tools & Alignment & - & Others & Literature Review \\
\hline 40 & Chen, L. & 2010 & Context & Alignment & Firm & Quantitative & Questionnaire \\
\hline 41 & Tallon, P. P. & 2010 & Context & Alignment & Industry & Quantitative & Questionnaire \\
\hline 42 & $\begin{array}{l}\text { Bulchand-Gidumal, J. and S. } \\
\text { Melián-González }\end{array}$ & 2011 & Impact & Evaluation & Firm & Quantitative & Questionnaire \\
\hline 43 & Valorinta, M. & 2011 & Impact & Alignment & Firm & Quantitative & Questionnaire \\
\hline 44 & $\begin{array}{l}\text { Mirchandani, D. A. and A. L. } \\
\text { Lederer }\end{array}$ & 2012 & People & Human related & Firm & Quantitative & Questionnaire \\
\hline 45 & Yayla, A. A. and Q. Hu & 2012 & Context & Alignment & Government & Quantitative & Questionnaire \\
\hline
\end{tabular}




\section{About the Authors}

Alireza Amrollahi received his master in IT management from the University of Tehran. $\mathrm{He}$ is currently a PhD student at the school of Information and Communication Technology (ICT) at Griffith University. His research interests include strategic planning for information systems, open source and collaborative approaches for software and content development.

Dr Amir Hossein Ghapanchi is a faculty member at Griffith University, school of ICT. He received his PhD from UNSW. Amir is an associate editor for Australasian Journal of Information System, and International Journal of Enterprise Information Systems. He is also an editor for the book of "Healthcare Informatics and Analytics: Emerging Issues and Trends" published by IGI Global. Amir has published over 25 peer reviewed journal papers and has served in several national information system projects. His main research interests include software project management, medical informatics, e- government planning and implementation, and multi-criteria decision making (MCDM). Amir has published in several prestigious management and information system journals such as Information and Organization, International Journal of Project Management, Journal of Systems and Software, International Journal of Information Management, and Electronic Markets.

Dr Amir Talaei-Khoei is a faculty member at USC and coordinator for a research initiative called "Assistive Technologies in Aged Care". He has previously received research grants from auDA and ANZ Trustee. He was awarded his PhD from the University of New South Wales. He has published in several prestigious information system journals such as International Journal of Medical Informatics, Journal of Systems and Software, and Journal of Computer and System Sciences. Amir is an associate editor for Australasian Journal of Information System, and Health Informatics. 